\title{
FACING THE GENERATION CHASM: THE PARENTING AND TEACHING OF GENERATIONS Y AND Z
}

\section{Rika Swanzen}

\begin{abstract}
The Millennials, or Generation Y, have been receiving increasing attention as these young people have entered tertiary institutions and the workplace over the past decade. Their behavior towards authority is coming under sharper scrutiny as they prepare to move into leadership positions. For example, their assertiveness received both positive and negative attention in the South African media during the "fees must fall" campaign. While parents, caregivers, teachers, and employers wonder about the best approach to Millennials, Generation $\mathrm{Z}$ are also entering post-secondary schools. Parenting approaches and the role of technology are being reevaluated. Within this context the article provides strategies that might be used to understand and guide these generations, thus helping avoid a generation gap that would threaten healthy relationships with our youth. After highlighting the differences between the attributes of these generations of young people and the generations who raised them, concepts such as character qualities, digital nativeness, and global civic engagement will receive attention. The convergence of such concepts will be used to recommend strategies for use in the parenting and teaching of Generations $\mathrm{Y}$ and $\mathrm{Z}$.
\end{abstract}

Keywords: millennials, generation gap, transformational learning

Rika Swanzen PhD is the Cluster Manager for Human and Health Sciences at Monash South Africa and is Adjunct Associate Professor with the Department of Social Work at Caulfield, Monash University, 144 Peter Road, Ruimsig, Gauteng, 1725, South Africa. Email: Rika.Swanzen@monash.edu 
In every generation, the profile of youth changes, and the nature of parenting and community involvement changes as well. Teaching in schools and universities seems slow to change, with little understanding of how big the generation gap between the student and teacher is becoming. How young people learn is inseparably linked to their future opportunities and wellbeing. For this reason, it is critical to consider for each generation who they are, how they process the world around them, how they engage with authority, how this impacts the family and the community, and what should be done to maximize the likelihood of them achieving their goals.

In this paper, a number of concepts will be brought together in an attempt to find teaching opportunities in the diverse and complex influences on the learning processes of the 21st century learner. I shall focus on three generations: Generation X (Gen X, 1965-1985); Generation Y (Gen Y, 1978-2000), also known as the Millennials; and Generation Z (Gen Z, 1995-2012). See Table 1 for an overview of the generations.

I will give a brief description of who Gen $\mathrm{Y}$ and Gen $\mathrm{Z}$ are, then explore the characteristics of the generations and the effects of parenting and culture on them in order to develop recommendations for teaching strategies, keeping in mind that, as parents, teachers, and employers, Gen X has a great influence on Gen Y and Gen Z. A brief overview of current educational opportunities and the role of civic engagement are also included to broaden the context of the discussion. Because the emphasis of the paper is on understanding the young generation seeking to be taught, "teaching" here includes both parents' and teachers' attempts to influence these young people: both parenting and teaching influences are discussed with a view towards providing recommendations for teaching strategies.

The youngest members of Gen $\mathrm{Y}$ and the members of Gen $\mathrm{Z}$ are currently entering training, higher education, or the workplace. I believe that, as caregivers and teachers, this is the moment to reflect on what we have learnt about Gen Y so as not be caught off guard by Gen Z. When I discuss teaching strategies, it will become clear that teachers and caregivers may not have adjusted well to the Millennial generation. It cannot be considered ideal that it has taken more than a decade to respond to the unique needs of a generation of young people.

\section{Generations in the 20th and 21st Centuries}

Gen Y are sometimes also called "the Millennials" because they would have begun reaching the age of eighteen and entering college or the adult workforce at the turn of the millennium. As the children of Baby Boomers, their number is expected to exceed even that of the large Baby Boomer generation. The Pew Research Centre estimated, from 2016 U.S. Census Bureau projections, that the Millennials will overtake the aging Baby Boomers in numbers in 2019 (Fry, 2018). 
International Journal of Child, Youth and Family Studies (2018) 9(2): 125-150

According to DeVaney (2015) there are some likely differences between younger and older Millennials. The oldest Millennials entered the job market during the multiyear recession beginning in 2008, while the youngest are still obtaining their education. Millennials have responded to the recession in different ways, such as engaging in social protests, moving back in with their parents, delaying marriage, delaying buying first homes, and starting their own businesses. The Millennials are expected to become the most educated generation ever, and are also the generation with the most student debt (DeVaney, 2015).

Since the early 2000s universities have faced the challenge of accommodating the Baby Boomers, Gen X, and Gen Y, three distinct generations, as teachers and students (Jonas-Dwyer \& Pospisil, 2004). The technologically savvy Gen Y students have new requirements and expectations of the learning environment (Jonas-Dwyer \& Pospisil, 2004). In the past decade, teachers focused on adapting to the new teaching needs while still fulfilling the educational expectations of students with more traditional requirements. The next decade will see another generation entering universities, with the previous cohort of students from the Baby Boomers and Gen X now being the lecturers of Gen Y and Gen Z (Shatto \& Erwin, 2016). According to Dziuban, Moskal, and Hartman (2005, p. 87):

Generation X experienced a significantly different set of markers from the Baby Boomers and was the first generation to feel the profound impact of technological developments. They encountered events such as Watergate, antiwar protests, excessive inflation, massive layoffs, the Challenger tragedy, the energy crisis ... [and] AIDS.... After school they became resourceful, since both parents were working, forming the first "Latch Key Generation." As a result, GenXers grew up skeptical and mistrustful of established organizations, institutions, and traditions.

Gen X stand up for themselves in the workplace and do not put much faith in future job security. Interestingly, the unprecedented media exposure to scandals and dishonesty in industry and the government also influenced Gen Y to challenge traditions, institutions, values, and people in authority (Dziuban et al., 2005).

Jonas-Dwyer \& Pospisil (2004, p. 194) summarize key trends of the 1990s and 2000s that influenced Millennials, such as "a focus on children and the family; scheduled structured lives; multiculturalism; terrorism; heroism; patriotism; parent advocacy and globalism". Shatto \& Erwin (2017) add that the Millennials and Gen Z possess characteristics that are unique to growing up in the Digital Age. Information is shared and streamed in real time, with civil uprisings being organized via social media. On the other hand, non-traditional families and exposure to different cultural perspectives makes Gen $\mathrm{Z}$ more accepting and open-minded of differences, leading to the most diverse generation (Shatto \& Erwin, 2016, 2017). Dorsey (TEDx Talks, 2015) stated that they are so accustomed to diversity, that they don't take note of diversity unless it is absent. 
International Journal of Child, Youth and Family Studies (2018) 9(2): 125-150

Table $120 t h$ and 21st Century Generations

\begin{tabular}{|c|c|c|c|c|}
\hline Century & Generation & Sub-/micro-generations & Born between & Notable occurrences \\
\hline 20 th & & G.I. Generation & $1900-1927$ & WWII in adulthood \\
\hline & $\begin{array}{l}\text { Greatest } \\
\text { Generation }\end{array}$ & Silent Generation & 1925-1945 & $\begin{array}{l}\text { WWII in childhood } \\
\text { Civil rights movement } \\
\text { Great Depression }\end{array}$ \\
\hline & Baby Boomers & $\begin{array}{l}\text { Boom Generation } \\
\text { Hippies }\end{array}$ & 1946-1964 & $\begin{array}{l}\text { Space exploration } \\
\text { First modern counterculture } \\
\text { Woodstock } \\
\text { Women's liberation movement } \\
\text { Economic prosperity }\end{array}$ \\
\hline & & $\begin{array}{l}\text { Baby Busters } \\
\text { Lost Generation } \\
\text { Latchkey Generation }\end{array}$ & 1965-1980 & $\begin{array}{l}\text { Vietnam War } \\
\text { Cold War } \\
\text { Independence / unsupervised after } \\
\text { school / self-care at a young age }\end{array}$ \\
\hline & Generation X & $\begin{array}{l}\text { MTV Generation } \\
\text { Boomerang Generation }\end{array}$ & 1975-1985 & $\begin{array}{l}\text { Rise of mass media } \\
\text { Lessening Cold War tensions } \\
\text { Graduated during a recession } \\
\text { Family instability }\end{array}$ \\
\hline & & $\begin{array}{l}\text { Xennial } \\
\text { Gen Catalano }\end{array}$ & 1977-1983 & $\begin{array}{l}\text { Analogue childhood and digital } \\
\text { adulthood } \\
\text { Bridged the generation gap }\end{array}$ \\
\hline & Generation Y & $\begin{array}{l}\text { Echo Boomers } \\
\text { Generation McGuire } \\
\text { Generation Me }\end{array}$ & 1978-1990 & $\begin{array}{l}\text { Rise of the Information } \\
\text { Age/Internet } \\
\text { War on Terror/Iraq War } \\
\text { Rising gas and food prices }\end{array}$ \\
\hline & & $\begin{array}{l}\text { Millennial } \\
\text { Net Gen }\end{array}$ & 1981-2000 & $\begin{array}{l}\text { School shootings } \\
\text { Novel modes of communication }\end{array}$ \\
\hline \multirow[t]{3}{*}{$21 \mathrm{st}$} & & $\begin{array}{l}\text { Gen } 2020 \\
\text { Post-Millennials } \\
\text { iGeneration }\end{array}$ & 1994-2007 & $\begin{array}{l}\text { Dot com bubble } \\
\text { Digital globalization } \\
\text { Cyber Bullying }\end{array}$ \\
\hline & Generation Z & $\begin{array}{l}\text { Centennials } \\
\text { Homeland Generation } \\
\text { New Silent Generation }\end{array}$ & 2005-2012 & $\begin{array}{l}\text { Declining birth/fertility rates } \\
\text { Movement towards nationalism } \\
\text { Great Recession } \\
\text { Physically inactive online time }\end{array}$ \\
\hline & $\begin{array}{l}\text { Generation } \\
\text { Alpha }\end{array}$ & $\begin{array}{l}\text { Gen Tech } \\
\text { Digital Natives }\end{array}$ & $2010-2025$ & $\begin{array}{l}\text { Shifts in global population } \\
\text { New climate of connectivity }\end{array}$ \\
\hline
\end{tabular}

Note. Adapted from Isacosta, n.d.; Matthews, 2008; Shafrir, 2011; Howe, 2014; Stankorb \& Oelbaum, 2014;

Sterbenz, 2015; Jenkins, 2017; and Zeigenhorn, 2017. 
See Table 1 for an overview of the generations of the 20th and 21st centuries, including world events that influenced each generation. This division of generations is defined in the context of Western culture, but Eastern and European definitions of cultural generations, based on other political, cultural and economic influences, have characteristics and behaviors that match their global peers more so than was the case in previous generations (Jenkins, 2017; TEDx Talks, 2015). Jenkins (2017) further highlighted that these are generalisations and that variations probably exist within generations. For this reason, the sub-generations (or microgenerations) cited from various sources are also included in Table 1.

Table 2 lists the needs of Gen X and Gen Y in the workplace. It provides a snapshot of the preferences of the two generations that currently find themselves in a multigenerational study or work environment. Table 2 also provides insight into the different approaches required by the Gen $\mathrm{X}$ teacher and the Gen Y learner. The understanding of Gen X forms an important background as the likely educators of Gen Y and Gen Z (Jonas-Dwyer \& Pospisil, 2004).

Table 2 Work needs of Gen $X$ and Gen $Y$

\begin{tabular}{ll}
\hline How to care for Gen X & How to care for Gen Y \\
\hline Communicate by voicemail or email & Use instant messaging or text \\
Reward with free time \& opportunities & Give awards \& certificates \\
Support training \& growth & Coach and support them \\
Give them freedom & Be collaborative \\
Think globally & Value civic duty \\
Don't micromanage & Provide flexibility \\
Give timely, specific feedback & Be motivational \\
Provide the latest technology & Value their technical savvy \\
Make it fun & Care about their personal goals \\
Value diversity & Promote volunteerism \\
\hline
\end{tabular}

Note. Adapted from Colligan, 2013a, 2013b.

Furthermore Hess (TEDx Talks, 2011) explains some of the differences between Gen X and Gen Y that can lead to misunderstanding between the generations. Jenkins (2017) also enumerates the characteristics of the two generations and these are listed with the mentioned differences in Table 3. 
International Journal of Child, Youth and Family Studies (2018) 9(2): 125-150

Table 3 Differences between Gen $X$ and Gen $Y$

\begin{tabular}{ll}
\hline Gen X & Gen Y \\
\hline Self-reliant & Creative - ask 'why' \\
Described as "slackers": leaning backward & Described as "engaged": leaning forward \\
Cliquish & Inclusive and tolerant \\
Sceptical and judgemental & Entrepreneurial \\
Anti-corporate & "Commerce must be lubricated by conscience" \\
Parents were authoritative, setting boundaries & Parents are friends and helpers, cheerleaders \\
\hline
\end{tabular}

Note. Adapted from Hess (TEDx Talks, 2011) and Jenkins, 2017.

Jenkins (2017) noted that Gen Z's approximate age by 2017 was younger than 19 years. While Gen Y and Gen Z have much in common, Table 4 shows some of the differences between them.

Table 4 Differences between Gen $Y$ and Gen Z

\begin{tabular}{ll}
\hline Gen Y & Gen Z \\
\hline Tech savvy: 2 screens & Tech innate: 5 screens \\
Think in 3D & Think in 4D \\
Collaborative & Pragmatic \& cautious \\
Radical transparency: share all & Judiciously share (GeoLoco off) \\
Slacktivists & Active volunteers \\
Multicultural & Blended (race \& gender) \\
Tolerance & Togetherness \\
Immature & Mature \\
Communicate with text & Communicate with images \\
Share stuff & Make stuff \\
Have low confidence & Have humility \\
Now focused & Future focused \\
Optimists & Realists \\
Want to be discovered & Want to work for success \\
Team orientation & Collective conscience \\
\hline
\end{tabular}

Note. Lolarga, 2016.

Two differences that are already noticeable between the generations of the 20th and 21st centuries are the need for the older members of Gen Y and Gen Z to involve themselves in society in a meaningful way and their increased acceptance of diversity. 
International Journal of Child, Youth and Family Studies (2018) 9(2): 125-150

In South Africa, when it was proposed that university fees be raised, the response of the Millennials enrolled at public universities made society aware of their plight in a very visible way. Through social media, a diverse group of students, supported by members of the public, quickly brought the protests to national attention and challenged mainstream media (see https://memeburn.com/2015/10/feesmustfall-how-sas-students-are-using-social-to-subvert-

traditional-media-narratives/). Their actions led to the government calling for special meetings to discuss the "higher education crisis". Not only did the young students demand a waiving of university fees, but they also demanded a decolonialization of the higher education (HE) curriculum. Since a media analysis does not fall in the scope of this article, I am only sharing from personal observations of social media between October and November 2015 and the start of 2016. There was some tension between those representing institutions, who thought that students wanted services for free and were following hidden political agendas, and the students, who felt frustrated with what they perceived to be empty promises and with being excluded from university because of unpaid debt. While for many students the "fees must fall" campaign was a call to activism, there was also a section of the student population who did not participate and who were disturbed by the fact that an academic year was lost through the obstruction of access to classes by their fellow students.

\section{Characteristics of Gen Y and Gen Z}

Jonas-Dwyer and Pospisil (2004) stated that:

According to Howe (2003) the Millennial generation are confident, happy, and optimistic. They are "risk-averse, ... and like to work with the best and latest hightechnology gadgets. The Millennials are into teamwork, group projects, servicelearning, and community service." (p. 196)

Furthermore, they are described as "sociable, optimistic, talented, well-educated, collaborative, open-minded, influential and achievement-oriented" (Raines, 2002 in Jonas-Dwyer $\&$ Pospisil, 2004, p. 195). These authors find the communication preferences of Gen $\mathrm{Y}$ to be electronic, positive, motivational, and goal-focused. Their modes of email and instant messaging, which they use for socializing and teamwork, should be catered to (Jonas-Dwyer \& Pospisil, 2004). Shatto and Erwin noted that, "The use of social media sites such as Tumblr and Twitter are gaining popularity as a way to have students connect with each other as well as post reflections and answer questions" (p. 26). Gen Z prefers social networks like Snapchat, Whisper, and Secret, while a quarter of 13 to 17 year olds are estimated to have left Facebook in 2017 and the most used website is YouTube (Valdeavilla, 2017).

Gen Y has a global orientation and understands the need for interconnectivity in the worldwide market (Nicholas, 2008). Dziuban and colleagues (2005) mention that Millennials are seen as "stimulus junkies", gamers, confident, sheltered, and demanding immediate response. Virginia Matthews (2008) quotes Keith Dugdale from KPMG (UK): "Although they have been 
International Journal of Child, Youth and Family Studies (2018) 9(2): 125-150

dismissed as the 'Silent Generation' on account of the time they will spend online, Gen Z may prove to be more imaginative than the rest of us".

\section{Influence of Technology}

While Gen X was the first to be exposed to widespread digital technology, the personal use of that technology has had a much greater impact on Millennials. Skinner (2015) said:

The millennials have never known a world without computers, the internet, mobile phones and other mobile devices. Their daily lives are all about being digital. They share their experiences on Facebook; read Yelp reviews before making purchases; and Tweet about the service they receive from retailers, banks, restaurants ... The term millennials has been used to describe young people (most of them born after 1980) who hold a strong influence over older generations and are paving the way for their elders to be just as digitally savvy. (p. 31)

According to Shatto and Erwin (2017), Millennials were the first generation to have computers in their schools and, together with Gen Z, are characterized by a propensity to multitask. Both generations also seem engaged when given the autonomy and freedom in their use of digital technologies. Nicholas (2008) stated that Millennials prefer a blend of collaboration, interdependence, and networking; their technology, like instant messaging and chat rooms, brings them together. The Baby Boomers specifically struggle with quickly changing technology, and this, "coupled with differences in work habits and learning styles, can cause conflict between members of older and younger generations" (Shatto \& Erwin, 2017, p. 25). While Gen X students tended to cynicism but were less apt to use critical thinking, Gen Y students' use of technology caused disruption during learning experiences in class (Robey-Graham, 2008).

Millennials are technologically savvy, and their high expectations pose a challenge for educational institutions, as Jonas-Dwyer and Pospisil (2004) explained:

The aging infrastructure and the lecture tradition of colleges and universities may not meet the expectations of students raised on the Internet and interactive games.... Students who have grown up with technologies have an information-age mindset, therefore demands on academic staff teaching the new millennial generation of students will be many - the requirement to increase their technological skill-base, to design teaching and learning activities to meet the change in students' learning styles and expectations, the need to be able to communicate with students through a range of media, and to interact and provide support 24 hours a day, seven days a week. (pp. 196, 200, 201).

As these authors also point out, the level of adjustment by academics will be dependent on their willingness to innovate and to experiment with new teaching and learning approaches. 
International Journal of Child, Youth and Family Studies (2018) 9(2): 125-150

\section{Parenting}

The other significant influence on the Millennial generation is parenting. Jason Dorsey (TEDx Talks, 2015) stated that "parenting is the greatest trend that influences behavior across generations." Reflecting on the parenting of one generation also provides insights for the next generation of parents.

Nicholas (2008) claims that Millennials present as entitled and empowered, and that this is partly due to being included in decision-making since childhood. They also get their sense of realism from the influence of the Baby Boomers' pragmatism and the Gen Xers' skepticism. Exposure to real-time war, reality television, and relative wealth has influenced their outlooks (Nicholas, 2008). As the children of "helicopter parents" who "hover" over their children in every aspect of their lives, this generation's experiences in school and society have been guarded, with less free time than any other generation. On the other hand, "Howe (2003) says the environment in which they have grown up has placed them under considerable pressure to achieve. He also says they are goal-oriented and pressured, worried about their security and sleep-deprived whilst in high school.” (Jonas-Dwyer \& Pospisil, 2004, p. 196).

Jenkins (2017) describes the Baby Boomers as driven, questioning authority, optimistic, efficient, team players, and great consumers. These traits undeniably shaped parenting behaviours. According to Howe (2014) the push for greater sheltering by the authoritative Baby Boomer parents was followed by Generation X parents who further emphasized protection, with a focus on adopting measures that did not exist or were not needed in earlier times, such as keeping baby bottles and toys free of substances like bisphenol A and using state-of-the-art strollers. This trend seems to favor a more traditional style of parenting, in terms of bedtimes, scheduled mealtimes and playtimes, stay-at-home moms, home-schooling, breastfeeding, and attachment parenting (Howe, 2014). Boomers tended to emphasize spending quality time with their children. Rather than adopting the Boomer's drive to raise "perfect" children, Gen X focus more on the quantity of time spent with children, and with employing tangible practices to keep children safe and wellbehaved (Howe, 2014).

Malone (2007) wrote about the childhood of Gen Z in suburban homes with fenced backyard spaces and limited interactions with other children in the neighbourhood streets and parks, which were viewed as unsafe for unsupervised children. Malone acknowledged that the Australian context of her study differs from that of a country like Germany where most children are allowed to travel by themselves. In a large study of 8.44 million adolescents in seven nationally representative surveys, it was found that the developmental pathway of adolescence had slowed, with childhood lasting longer and young people taking on adult responsibilities later in life (Twenge \& Park, 2017). Lolarga (2016) provided an interesting viewpoint on Gen $\mathrm{Z}$ as likely to grow into adulthood much earlier than Gen $\mathrm{Y}$, as they are being raised by more pragmatic Gen $\mathrm{X}$ parents who encourage their Gen $\mathrm{Z}$ children to be more independent. These parenting styles have 
International Journal of Child, Youth and Family Studies (2018) 9(2): 125-150

had an influence on these students' teaching preferences. Valdeavilla (2017) proposed that $42 \%$ of Gen Z children will follow their parents' example as compared to the $36 \%$ of Gen Y children.

\section{Changes in the Education Environment}

Jonas-Dwyer and Pospisil (2004, p. 195) observed that, "For a number of years now the technological revolution has been a catalyst for change in universities, but research has shown that introducing new educational technologies alone does not improve teaching and learning outcomes." On this basis they suggest a holistic approach to teaching, and the development of blended learning environments, which will receive attention in a later section.

In South Africa the Council of Higher Education (CHE) released a report in 2016 on the previous 20 years of transformation in HE:

The government's espoused policy of pursuing "fee-free education for the poor" has led to widespread misunderstanding of what is intended, and added fuel to the many student protests related to demands for government "to open its coffers".... The student protests are often volatile and some have led to violence and damage to property. Indeed, this and the harder edge to charges of racism and calls for institutional transformation have contributed to potential instability in the system twenty years after the change to democracy. The combination of limited financial assistance, poor throughput rates and pressure to increase participation has created arguably the most difficult challenge for the higher education system to manage. (CHE, 2016, p. 29).

A well-managed transformation implemented by the higher education sector resulted in the increase in the number of students entering from diverse backgrounds, many of them firstgeneration immigrants, and from previously disadvantaged demographics. This necessitated changes in organizational structures, the size and shape of systems, curriculum, mode of delivery and pedagogy, and research (CHE, 2016). Changes included the large-scale introduction of bridging and foundation programs; more relevant and outcomes-based curricula; open learning or blended approaches to teaching; short courses to supplement workplace experiential learning; more explicit and transparent expectations and criteria for assessment; external quality assurance, considering fit for purpose; and a reconsideration of the relationship of institutions with external communities (CHE, 2016, pp. 10, 12, 16, 30).

The increase in the complexity of HE becomes evident when all of these changes in the last two decades are considered. Added to this is the new call for:

African scholarship, or what it means to be a university in South Africa and what knowledge is appropriate for this context. Yet there are also strident calls for a transformation of the curriculum that berate Eurocentricism, some of which appear 
International Journal of Child, Youth and Family Studies (2018) 9(2): 125-150

to endorse a fairly narrow view of what is appropriate in a local context. (CHE, 2016, p. 15)

Some of the discourse reflected on by the report also involves the reimagining of what possibilities exist, with a rapidly growing global middle class, for "developing curricula that are simultaneously relevant to current South African students and which lead to extending the boundaries of current knowledge in a way that transcends the local" (CHE, 2016, p. 15).

Not only is the training institution required to establish a relationship with the community, but the Millennial student also requires a relevant curriculum, while Gen $\mathrm{Z}$ expects to be actively involved in service to society. Millennials prefer teamwork, group projects, service-learning, and community service. Thus higher education institutions should be prepared for these students who expect a lot, and should stress good outcomes, use social norming, and create the expectation of success for all (Jonas-Dwyer \& Pospisil, 2004, p. 196). To place the expectation for servicelearning and community service into a context of learning, civic engagement will be discussed before moving to an inclusive discussion on and illustration of teaching strategies.

\section{Civic Engagement}

According to Bringle, Phillips, and Hudson (as cited in Swanzen \& Graham, 2016):

Service-learning is a course-based, credit-bearing educational experience in which students participate in an organized service activity that meets identified community goals. Reflection is used for the student to gain further understanding of course content, a broader appreciation of the discipline, and an enhanced sense of civic responsibility. (p. 285)

Both the community and students need to be beneficiaries, and the goals include both service and learning. A reciprocal relationship occurs in cycles of contact and collaboration under favorable conditions and takes place through negotiation, agreement, and mediation with communities (Smith-Tolken \& Bitzer, as cited in Swanzen \& Graham, 2016, p. 285).

Swanzen and Graham (2016, p. 299) considered various core concepts that describe the relationship between active citizenship and service-learning in higher education resulting in the following core definition of student active citizenship through service-learning:

Understanding, acknowledging and safeguarding the rights and responsibilities of the student and the community (separately but also in their relationship together) in the student's active learning in and civic engagement with the community whilst always being mindful of serving the public good.

Implementing active citizenship in the classroom involves long-term sustainable partnership development work. Matthews (2008) predicted that "political life will become less significant as Gen Z-ers exercise power via their online identities, not the ballot box". Insights 
International Journal of Child, Youth and Family Studies (2018) 9(2): 125-150

from McMillan and Stanton (2014) and from Mitchell (2008) were considered by Swanzen and Graham (2016), and some of the guidelines are summarized as follows:

- To understand how the community fits into the larger power environment or political landscape;

- To ensure that the essential nature of the student is visible and present in the learning process and to focus the curriculum on understanding (knowledge), doing (skills), and being (self), with most of the emphasis on the latter;

- To resist the pressure to prioritize goals and outcomes at the expense of sustaining relationships; and

- To have a commitment to dialogue (formal and informal exchanges in and out of the classroom), self-awareness (acknowledging how our backgrounds and personal prejudices may influence our perceptions and actions), the capacity for critical reflection (questioning our beliefs, assumptions and values as well as our motivations and intentions in our community engagement), and solidarity (students use their service experience to generate a genuine desire for broader social justice).

According to Jonas-Dwyer and Pospisil (2004), a holistic approach that looks at teaching and learning strategies from an integrated perspective may offer the greatest impact. Such an approach uses multiple strategies, and also requires taking into account the changing student generation.

\section{Teaching Strategies}

To accommodate the communication and learning preferences of the 21 st century student, various strategies have been suggested. Jonas-Dwyer and Pospisil (2004) postulate that, Gen Y having been exposed to new technologies, they would likely expect academic staff to be comfortable with a wide range of current technologies and to utilize them in their teaching. However, skills in technology are not the only expectation of this generation, which is why these authors propose holistic development, as discussed later.

Dziuban et al. (2005, p. 97) observed that "some characterize the Millennials by their technological empowerment" and preference for multitasking, while "others ... suggest that Millennials are not proficient in higher order thinking, and are unwilling to take intellectual risks and view problem-solving as a series of choices on a monitor." Shatto and Erwin (2016) stated that, more than any other modern generation, Gen $\mathrm{Z}$ students learn by observation and practice and not through reading and listening. Their ability to obtain information from online sources seems impressive, but they lack the ability to critique the validity of the information, and are likely to get frustrated if answers are not clear immediately. Thus, keeping the attention of the student and developing higher order thinking skills are critical components of successful teaching. 
International Journal of Child, Youth and Family Studies (2018) 9(2): 125-150

Multigenerational learning approach: In her doctoral study, Robey-Graham (2008) defined "transformational learning" as a process

where students moved from being unaware of the world around themselves to embracing new perspectives which changed their lives. The process included constructing meaning of their world; reflecting on personal assumptions, beliefs, attitudes, feelings; discourse to discuss old and new ideas; and action based on new lenses for viewing their world. (p. 27)

Three results emerged from Robey-Graham's doctoral study (2008, p. iii): (a) the advantage of the synergy that occurs in multigenerational classrooms, which impacted the potential for transformational learning; (b) how multigenerational learning impacted theoretical perspectives and how the faculty can incorporate generational theory as they design learning activities; and, (c) how and why some Millennial students' behaviors related to the use of personal technology not only caused them to avoid transformational learning, but also adversely affected the learning of others in the classroom.

Key to this author's proposed theoretical foundation for her study was that transformational learning can serve as a bridge between the different generations found in a classroom. RobeyGraham (2008) explained that change is brought on by critical reflection by the learner on his or her own assumptions that are then tested through engagement with others, leading to acting upon the new meanings allocated to the experience:

Transformational learning theories emphasized the critical importance of the learners' experience and moving learners through phases that helped them reflect on their own assumptions and biases as they grew more aware, engaged in discourse to discover new ways of thinking, and then moved to action. (p. 8)

Facing the generational chasm involves recognition of the power of transformative interactions between learner and teacher.

Blended-learning approach: Dziuban and colleagues (2005) were of the opinion that "designing a blended-learning course that maximizes the potential of both the face-to-face and online components raises questions: What is the best definition of blended learning? How much of each modality should comprise a course?" (p. 96). They also felt it important to consider how best to integrate the face-to-face and online elements of a course.

A reason for the diminished acceptance of blended learning by Gen $\mathrm{Y}$ is their need for a team orientation, while the $\mathrm{HE}$ milieu persists in emphasizing individual accomplishment (Dziuban et al., 2005). The "challenge, then, is to develop teaching and learning strategies for the blended learning environment that will capitalize on the Millennial students' strengths while accommodating their immaturity" (Dziuban et al., 2005, p. 97). Jarvela and Niemivirta (1999) indicated that self-regulation in learning is not given by the learning environment, but lies in the 
dynamic interaction between the student's motivation and situational interpretations being produced. Students do not passively absorb knowledge but actively construct it from previous experiences. The learning environment should therefore provide opportunities for the student to test new conceptual understanding (Jarvela \& Niemivirta, 1999), and this constructivist approach should remain part of the creation of a blended-learning environment.

Situational learning: Because radical constructivism has been criticized for separating knowledge from the situations in which it is learned and used (Jarvela \& Niemivirta, 1999), it is further necessary to place learning within the framework of a service-learning and civic engagement context as previously discussed. In a social constructivist approach, the cultural context of the student becomes an important filter through which meaning is applied. Such an approach lends itself to concepts of situated learning, where the aim is to turn learning situations into challenging and interesting projects requiring authentic problems to be solved (Jarvela \& Niemivirta, 1999).

A learning situation is not only a mental performance for the student, but also a motivational and emotional challenge (Jarvela \& Niemivirta, 1999). While social and emotional learning theory will not receive attention in this article, it is worthwhile to note the need to consider the influence of learning theories on the creation of a learning environment. What is given a focus in the learning environment should also be considered in assessing the impact of generational and cultural constructions on self-regulation during the learning process. "Because learning is determined as a communal function of keeping up cultural traditions, institutional learning, too, should take place in authentic and complex social contexts" (Jarvela \& Niemivirta, 1999, p. 62).

Collaborative and cooperative learning: Earlier research on the development of expertise has shown that a "prerequisite for the accumulation of higher order knowledge and taskoriented commitment is partnership in a social environment" (Jarvela \& Niemivirta, 1999, p. 62). Previously, it was feared that the need of 21 st century students to participate in collaborative learning, both formal and informal, would lead to weakened motivation; however, what is essential is not the social context or collaboration per se, but how the activities are harnessed to enhance intentional learning (Jarvela \& Niemivirta, 1999). Igel and Urquhart (2012) indicated that within social learning, collaborative learning occurs when students work in groups, while cooperative learning is highly structured to ensure even participation among members. "When teachers use cooperative learning properly, they are more likely to reengage students who have become marginalized while better preparing all students to be successful in their future endeavours" (Igel \& Urquhart, 2012, p. 17). Igel and Urquhart (2012) outlined three principles for the successful implementation of cooperative learning, and how each could be accomplished:

- Teach group processing and interpersonal skills: teach small group skills with task management and role differentiation towards collective problem solving.

- Establish cooperative goal structures within groups: promote interdependence, linking outcomes among group members and sharing of resources. 
International Journal of Child, Youth and Family Studies (2018) 9(2): 125-150

- Provide mechanisms for individual accountability: limit groups to three to five members, have groups determine non-redundant roles upfront, and highlight the importance of unique contributions.

While social learning is not a new concept, it should not be forgotten but retained and pursued more purposefully in the light of new knowledge. In the case of social learning, the relationship with new concepts like service-learning, civic engagement, and cultural intelligence can be highlighted. Especially in the construction of a blended-learning environment, the focus cannot shift to offering merely the transfer of knowledge, whether face-to-face or in an online forum, but must remain on integrating relevant knowledge and nurturing intentional learning.

As an approach to multigenerational learning, transformational learning could be triggered by significant events or by exposure to other people who have different lenses on the world. Dialogue is the means for a shared relationship between teacher and student who together explore their common reality within a sociocultural context (Robey-Graham, 2008). When cooperative learning is pursued the generational differences should be utilized as part of the creation of a socially constructed and situation-based learning experience. Transformational learning can occur because of the generational difference that becomes evident where two sets of social frameworks interact.

Environmental scanning: Litshani (2017) stated that a responsive teaching environment considers not only the aspects of the subject matter and the learner, but also how economic and sociocultural aspects impact classroom practice. She suggested that the educator use environmental scanning, in which an analysis of strengths, weaknesses, opportunities, and threats (SWOT) is carried out on the various aspects of a teaching environment: global, continental, regional, institutional, and discipline or subject. An example of a weakness in the global aspect might be a lack of exposure to international conferences; a threat might be that globalization increases competition. Continentally, an opportunity could be that there is a synergy among networks, while weaknesses in the regional and national aspects could include unanswered communications and unclear policies and procedures. A strength in the institutional and subject matter aspect could be the presence of well-qualified teachers. (Litshani, 2017).

For each of these aspects the following questions should be answered for the enhancement of effective teaching (Litshani, 2017):

- How competent am I in each aspect and where are the gaps in my knowledge?

- What are the opportunities in this environment and what do I stand to gain or lose if they are pursued?

- Does the teaching and content respond to what learners are required to know in the job market? 
International Journal of Child, Youth and Family Studies (2018) 9(2): 125-150

Curriculum orientation: The significance of understanding the needs and strategies for teaching lies in curriculum responsiveness. Litshani (2017, p. 16) explained that:

Every curriculum is a product of its society's beliefs, needs and challenges ... curriculum responsiveness entails some positively formulated benchmarks against which we might be able to judge whether our educational programmes are meeting the needs of a transforming society.

Litshani (2017, pp. 17-18) explains that there are three main orientations towards curriculum:

- Curriculum as a product that is dependent on the setting of behavioral objectives, often presented in modularized forms.

- Curriculum as process that focuses more on the interaction between the student and teacher; it is therefore an active process, and links with practical forms of reasoning and meaningmaking.

- Curriculum as praxis and as epistemic, meaning that it does not make statements about the theoretical interests it serves. The development of the curriculum through a dynamic process of reflection and action leads to a diverse and socially inclusive curriculum.

It should be clear from the above description that meeting the different teaching needs of 21 st century students requires making a choice about the curriculum orientation that is to be followed on a more macro or institutional level (see Figure 1).

The young Domenico Randazzo (TEDx Talks, 2016a) questions the ability of the education system to meet the learning needs of Millennials. He sees creativity and passion as two key areas for personal development that is not encouraged by what he calls the "over saturation of wellroundedness". He proposes a vertical alignment of the curriculum to appeal to different fields of real-world interests. We can ask ourselves whether the subject choices in schools and even universities differ from 10 and 20 years ago. According to Lindsay Pollak (TEDx Talks, 2016b), in a 2012 survey, PricewaterhouseCoopers "asked Millennials, 'What is the most important factor to you in deciding to take a job?'. The number one answer by far was the opportunity for personal development: 'I want to grow'." She further spoke of a high-school football coach who shared during a media interview that he adjusted his style because he recognised that Millennials do not respond to punishment and yelling. Considering this, Pollak highlights the shift that is occurring in development and coaching functions. For example, some companies are replacing the annual performance review, which is viewed negatively, with real-time positive feedback through the use of technology, like instant messaging. It is clear how such trends should influence the way in which students are taught, especially with regard to consistent guidance and prompt feedback. 
International Journal of Child, Youth and Family Studies (2018) 9(2): 125-150

\section{Recommendations for Teaching Gen Y and Z}

The 21st century student's learning needs have been explored by different authors, whose contributions are integrated in Tables 5 and 6. As an introduction, the " 10 signs of a 21 st Century classroom", are listed by Goertz (2015) in his blog under the following headings: "Technology integration, collaborative environment, opportunities for creative expression, inquiry-based approach, justification for answers, writing for reflection, use of a problem-solving methodology, hands-on learning, teacher as facilitator, transparent assessment." While this list will generally serve both Gen $\mathrm{Y}$ and Gen $\mathrm{Z}$ in the classroom, Table 5 addresses the more specific learning needs of Gen Y, while Table 6 deals with Gen Z.

Table 5 Integration of Guidelines for Instruction and Teaching Needs for Gen $Y$

\begin{tabular}{ll}
\hline \multicolumn{1}{c}{ Guidelines for teaching } & \multicolumn{1}{c}{ Teaching needs } \\
\hline $\begin{array}{l}\text { Educate yourself about the concept of } \\
\text { generational differences. }\end{array}$ & Want to have a say in their education. \\
$\begin{array}{l}\text { Recognize the environmental and cultural } \\
\text { forces that affect the Millennial learner. }\end{array}$ & $\begin{array}{l}\text { Often have higher levels of digital literacy } \\
\text { than their parents or teachers. }\end{array}$ \\
$\begin{array}{l}\text { Understand how potential } \\
\text { intergenerational tension may impact }\end{array}$ & $\begin{array}{l}\text { Expect transparency in their parents, teachers, } \\
\text { and mentors. }\end{array}$ \\
learning: Avoid references to prior &
\end{tabular}

learning with little context.

Millennials need guidance and focus in their learning: can get content, but need help to synthesize, analyze, and apply.

Want you to tell them when you have messed up, apologize for it, and move on.

Identify your teaching or life philosophy: share and connect.

Don't care as much about having a job as they do about making a difference.

Learn how to utilize current eLearning technologies.

Demand the freedom to show their creativity and avoid rote learning.

Recognize that Millennials value (and expect) aesthetically appealing educational presentations.

Emphasize opportunities for additional help and support: raised by helicopter Want to connect with others in real time on their own terms.

Collaborate well and like to multitask. parents, comfortable with asking for help.

Encourage curiosity and exploration: "While the correct solution is important, the process by which one gets there is equally of interest and worthy of attention".

Recognize the importance of team dynamics and encourage collaboration:

Appreciate a "trial and error" approach to learning new skills and learn by doing. 
International Journal of Child, Youth and Family Studies (2018) 9(2): 125-150

\begin{tabular}{ll}
\hline \multicolumn{1}{c}{ Guidelines for teaching } & \multicolumn{1}{c}{ Teaching needs } \\
$\begin{array}{l}\text { less limited by preconceived notions of } \\
\text { roles. }\end{array}$ & \\
$\begin{array}{l}\text { Be fair and straightforward: scandals and } \\
\text { fallen leaders are common. }\end{array}$ & $\begin{array}{l}\text { Have multicultural awareness and } \\
\text { appreciation. Increasingly aware of the world } \\
\text { around them. }\end{array}$ \\
$\begin{array}{l}\text { Identify the limits of multitasking: } \\
\text { retention and recall fail. }\end{array}$ & $\begin{array}{l}\text { Open to change. Know where to go to find } \\
\text { information. }\end{array}$ \\
& $\begin{array}{l}\text { Are equal parts "consumer" and "creator". } \\
\text { Expect interdisciplinarity. }\end{array}$ \\
\hline
\end{tabular}

Note. Adapted from Eaton, 2012, and Roberts, Newman, and Schwartzstein, 2012.

As we are in a way still adjusting to the requirements needed for educating Gen Y, and as the younger part of Gen Y has joined the higher education or work sectors, the older part of Gen $\mathrm{Z}$ is already leaving school for work or studies. Strategies proposed by a number of authors for better aligning higher education with the needs of 21st century students have been included in this paper, but there are some who warn against such suggestions. Naomi Baron as cited in Barnes, Marateo, and Ferris (2007, p. 2) felt that "the move to incorporate technology, reduce lecture time, and reshape assignments to engage impatient Net Geners merely caters to a lack of discipline"; frequent use of electronic tools does not mean increased literacy or critical thinking skills. Shatto and Erwin (2017) indicate that innovative teaching using different forms of technology is required to fully engage Gen Z. Examples of forms of teaching technology are incorporated in Table 6. 
International Journal of Child, Youth and Family Studies (2018) 9(2): 125-150

Table 6 Integration of Teaching Needs and Guidelines for Instruction for Gen Z

\begin{tabular}{|c|c|}
\hline Guidelines for teaching & Teaching needs \\
\hline $\begin{array}{l}\text { Use mobile technology and apps when } \\
\text { possible. }\end{array}$ & $\begin{array}{l}\text { Feedback according to the individual } \\
\text { student's needs. }\end{array}$ \\
\hline $\begin{array}{l}\text { Use readings that can be completed on tablets } \\
\text { or smart phones. }\end{array}$ & Collaborative learning. \\
\hline $\begin{array}{l}\text { Encourage collaboration or cooperative } \\
\text { learning through use of social media sites } \\
\text { such as Facebook, Tumblr, Twitter, blogs, } \\
\text { and discussion groups. }\end{array}$ & $\begin{array}{l}\text { Methods such as flipped classrooms and } \\
\text { active learning allow students active } \\
\text { participation (e.g., case studies, group } \\
\text { projects, use of clickers for voting, blogs, } \\
\text { and critical thinking assignments). }\end{array}$ \\
\hline $\begin{array}{l}\text { Have students either find or make a YouTube } \\
\text { video about whatever subject they are } \\
\text { studying. }\end{array}$ & Reinforce concepts with YouTube videos. \\
\hline $\begin{array}{l}\text { Use interactive games such as Jeopardy, } \\
\text { Kahoot, and Socrative to encourage critical } \\
\text { thinking. }\end{array}$ & Learning process in a fun and modern way. \\
\hline $\begin{array}{l}\text { Incorporate laboratory skills into the } \\
\text { classroom. }\end{array}$ & $\begin{array}{l}\text { A reliance on internet search engines and } \\
\text { videos for research. }\end{array}$ \\
\hline $\begin{array}{l}\text { Videotape working professionals displaying } \\
\text { work skills and have students reflect and } \\
\text { report on it. }\end{array}$ & $\begin{array}{l}\text { Learn more by observation and experiential } \\
\text { practice. }\end{array}$ \\
\hline $\begin{array}{l}\text { Limit readings to include only necessary } \\
\text { information. }\end{array}$ & Teacher must interact more and lecture less. \\
\hline $\begin{array}{l}\text { Include discussions on inclusiveness and } \\
\text { tolerance. }\end{array}$ & Expect immediate answers. \\
\hline $\begin{array}{l}\text { Use narratives and storytelling when teaching } \\
\text { students from diverse backgrounds. }\end{array}$ & $\begin{array}{l}\text { Need to know the relevance of information } \\
\text { to their course. }\end{array}$ \\
\hline $\begin{array}{l}\text { Use group work that focuses on varying } \\
\text { viewpoints. }\end{array}$ & Want to learn by doing. \\
\hline $\begin{array}{l}\text { Use an inquiry-oriented lesson format such } \\
\text { as WebQuest to help students locate } \\
\text { information from the web. }\end{array}$ & $\begin{array}{l}\text { Born into a digital world, they need to learn } \\
\text { how to engage with the information that is } \\
\text { easily accessible. }\end{array}$ \\
\hline $\begin{array}{l}\text { Let students act as scribes of the lecture and } \\
\text { material - have students write the course } \\
\text { book for other students. }\end{array}$ & \\
\hline
\end{tabular}

Note. Shatto \& Erwin, 2016; Barnes, Marateo \& Ferris, 2007. 


\section{Holistic Academic Development}

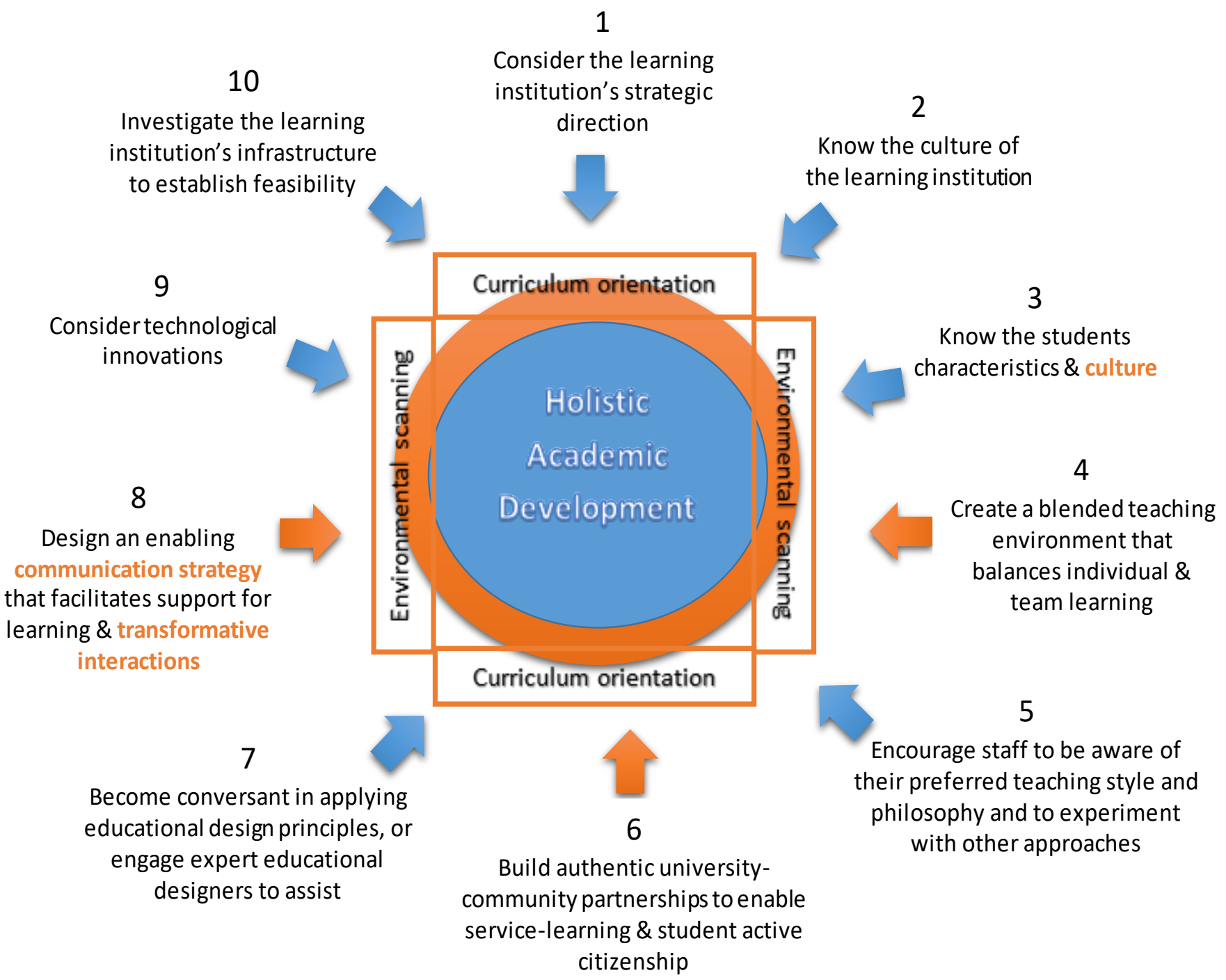

Figure 1. An integrated holistic academic development model. Adapted from Jonas-Dwyer and Pospisil, 2004, p. 202; Magano, Mohapi, and Robinson, 2017, pp. 16-17; Robey-Graham, 2008, p. 8; Swanzen and Graham, 2016.

A holistic approach to academic development or overall learning by the student would include all the factors that impact teaching, with a consideration of multiple strategies that are applied simultaneously (Jonas-Dwyer \& Pospisil, 2004). Buckley (as cited in Jonas-Dwyer \& Pospisil, 2004, p. 202) suggests that "adopting strategies that lead academic staff to a more learnercentred approach can be successful when aligned with the needs of staff and the institution". JonasDwyer and Pospisil (2004) identify "seven factors [that] contribute to a holistic academic development approach" (p. 202; see non-orange parts of Figure 1), and start with the statement that the success of creating optimal learning environments is dependent on the goals and quality of the institutional program. The university or any other learning institution's strategic direction 
needs to be considered in relation to all the other factors in Figure 1. Awareness of the current and evolving academic and university culture is critical, insofar as it impacts the success of any initiative. To know the characteristics of the student will help to determine the most appealing and successful teaching and learning strategies, as well as an awareness of the communication tools and styles that students use. Academics also need to be willing to experiment with styles that differ from their own teaching philosophies, and this must be done with the necessary institutional support. Academics need to become competent in applying educational design principles with the assistance of experienced educational designers. Teaching and learning that emphasizes the development of the whole person typically includes "collaborative and cooperative learning, active and service learning, learner-centred, lifelong learning, experiential, interactive and authentic learning, educational technology, internet integration, outcomes based education, knowledge of whole systems, emotional literacy, metacognition, multiple intelligences, and learning styles (Hanna, 2003; Weimer, 2002; Poindexter, 2003; Holistic Education Network of Tasmania, 2003)." (Jonas-Dwyer \& Pospisil, 2004, p. 203). The implementation of technological innovations should be coordinated with corresponding staff development activities. The school infrastructure should be explored to establish feasibility for the adoption of innovations.

Figure 1 shows all these factors, and I have made adjustments (in orange) to include other factors from previous discussions in this article. These include a specific consideration of blended and cooperative learning as a strategy for teaching the 21 st century student, the importance of the influence of culture, and a consideration of the need for significant partnerships with the community to assist with teaching in real-life situations. Also, because the change in the preferred style of communication by students is so significant, another factor that needs specific mention is the development of a communication strategy. Considering the communication needs of Gen Y and Gen Z, and employing resources such as instant messaging, will facilitate the transformative interactions to bridge the generational divide.

The orange circle around the blue circle at the center of Figure 1 represents two major influences when the 10 factors feeding into holistic academic development are considered. I propose that, for the purposes of this article, these are horizontal and vertical influences. The vertical influence involves environmental scanning (as discussed previously) of the various structures impacting the learning institution (global, continental, regional, and institutional). There is also a horizontal influence that involves decisions about the curriculum orientation, discussed at the end of the Teaching Strategies section. Decisions about curriculum can be considered laterally across different parts of the curriculum (benchmarks for responsiveness across teaching and assessment activities) and even across different disciplines and communities. 


\section{Conclusion}

Numerous aspects relating to the teaching of Generations $\mathrm{Y}$ and $\mathrm{Z}$ have been shared in this paper with the aim of demystifying the gap caused by the different perceptions held by the generations teaching or raising them. In addition, a number of teaching strategies have been provided to help bridge the chasm that can challenge the relationships between diverse generations.

After considering the role of parenting, civic engagement, the 21 st century student's needs, and influences from the environment, the key factors were incorporated into an integrated illustration showing how the holistic academic development of the 21 st century student can be achieved. This can be used to approach transformation in a comprehensive and responsible manner. While the focus has been on teaching, the generational insights are also relevant for parents who need to facilitate the learning of their child in the 21 st century.

It has been predicted that the generational spans are likely to decrease to 5 to 10 years instead of the traditional 15 to 20 years, because of increasing exposure to global events and innovations worldwide (Jenkins, 2017). Pollak (TEDx Talks, 2016b) stated that by 2025, Millennials will make up $75 \%$ of the workforce. Because of the pace of change in society, Dorsey (TEDx Talks, 2015) indicated that instead of the usual 3 or 4 generations present simultaneously in the workplace, it is likely that there will be a rise to 6 or 7 generations in the future. He further claimed that the influence within generations is now upward - the youngest generation influences the older ones. Given the role that higher education plays in the employability of graduates, it is critical that a flexible but focused approach to the teaching of the 21 st century student be adopted. 
International Journal of Child, Youth and Family Studies (2018) 9(2): 125-150

\section{References}

Barnes, K., Marateo, R. C., \& Ferris, S. P. (2007). Teaching and learning with the Net Generation. Innovate: Journal of Online Education, 3(4), Article 1. Retrieved from http://nsuworks.nova.edu/innovate/vol3/iss4/1

Colligan, K. (2013a). Managing Generation Xers in the multi-generation workplace [Blog post]. Retrieved from http://www.peoplethink.biz/category/multi-generational-workforce/

Colligan, K. (2013b). Recognizing the value millennials bring to the workplace [Blog post]. Retrieved from: http://www.peoplethink.biz/category/multi-generational-workforce/

Council for Higher Education (CHE). (2016). South African higher education reviewed: Two decades of democracy. Pretoria. South Africa: Author.

DeVaney, S. A. (2015). Understanding the millennial generation. Journal of Financial Service Professionals, 69(6), 11-14.

Dziuban, C., Moskal, P., \& Hartman, J. (2005). Higher education, blended learning, and the generations: Knowledge is power-no more. In J. Bourne and J. C. Moore (Eds.), Elements of quality online education: Engaging communities, pp. 85-100. Sloan-C Series (Vol. 6). Needham, MA: Sloan Center for Online Education.

Eaton, S. E. (2012). 21 characteristics of 21st century learners, Literacy, languages and leadership [Blog post]. Retrieved from https://drsaraheaton.wordpress.com/2011/12/07/21st-century-learners/

Fry, R. (2018). Millennials projected to overtake Baby Boomers as America's largest generation. [Blog post]. Retrieved from http://www.pewresearch.org/fact-tank/2018/03/01/millennialsovertake-baby-boomers/

Goertz, P. (2015). 10 signs of a 21 st century classroom [Blog post]. Retrieved from http://www.edutopia.org/discussion/10-signs-21st-century-classroom

Howe, N. (2014). Introducing the Homeland Generation (Part 1 \& 2). Retrieved from https://www.forbes.com/sites/neilhowe/2014/10/27/introducing-the-homeland-generationpart-1-of-2/\#7bce43102bd6 \& https://www.forbes.com/sites/neilhowe/2014/10/31/introducing-the-homeland-generationpart-2-of-2/\#1d6cfcbccbb6

Igel, C., \& Urquhart, V. (2012). Generation Z, meet cooperative learning: Properly implemented cooperative learning strategies can increase student engagement and achievement. Middle School Journal, 43, (4), 16-21. doi:10.1080/00940771.2012.11461816 
International Journal of Child, Youth and Family Studies (2018) 9(2): 125-150

Isacosta (n.d.). List of generations chart. Retrieved from http://www.hbcukidz.co/uploads/8/2/0/0/8200815/generations_chart.pdf

Jarvela, S., \& Niemivirtab. M. (1999). The changes in learning theory and the topicality of the recent research on motivation. Research Dialogue in Learning and Instruction, 1, 57-65. doi:10.1016/S0959-4752(99)00009-2

Jenkins, R. (2017, July 30). Who are the generations? [Video file]. Retrieved from https://www.youtube.com/watch?v=IYOeDIOxKjc

Jonas-Dwyer, D., \& Pospisil, R. (2004). The Millennial effect: Implications for academic development. Research and Development in Higher Education: Transforming Knowledge into Wisdom, 27, 194-206. Retrieved from

http://www.herdsa.org.au/publications/conference-proceedings/research-and-developmenthigher-education-transforming-18

Litshani, N. F. (2017). Positioning and realigning the role of the teacher for classroom practice. In M. D. Magano, S. J. Mohapi, \& D. Robinson (Eds), Realigning teacher training in the $21^{\text {st }}$ century. Andover, United Kingdom: Cengage Learning EMEA.

Lolarga, J. (2016, March 1). Millennials vs Gen Z: Understanding generational preferences \& their motivations [Blog post]. Retrieved from: https://www.linkedin.com/pulse/millennialsvs-gen-z-understanding-generational-jacob-lolarga

Malone, K. (2007). The bubble-wrap generation: Children growing up in walled gardens. Environmental Education Research, 13(4), 513-527. doi:10.1080/13504620701581612

Matthews, V. (2008). Generation Z: New kids on the virtual block [Blog post]. Retrieved from http://www.personneltoday.com/hr/generation-z-new-kids-on-the-virtual-block/

McMillan, J., \& Stanton, T. K. (2014). "Learning Service" in international contexts: Partnershipbased service-learning and research in Cape Town, South Africa. Michigan Journal of Community Service Learning, 21(1), 64-78.

Mitchell, T. D. (2008). Traditional vs. critical service-learning: engaging the literature to differentiate two models. Michigan Journal of Community Service Learning, 14(2), 50-65

Nicholas, A. (2008). Preferred learning methods of the Millennial generation. Faculty and Staff Articles \& Papers, Paper 18. Retrieved from http://digitalcommons.salve.edu/fac_staff_pub/18

Roberts, D. H., Newman, L. R., \& Schwartzstein, R. M. (2012). Twelve tips for facilitating Millennials' learning. Medical Teacher, 34(4), 274-278.

doi:10.3109/0142159X.2011.613498 
International Journal of Child, Youth and Family Studies (2018) 9(2): 125-150

Robey-Graham, V. A. (2008, August). Teaching multi-generational students: A case study of community college classrooms (Unpublished doctoral dissertation). Arizona State University, Arizona, United States.

Shafrir, D. (2011). Generation Catalano: We're not Gen X. We're not Millennials [Blog post]. Retrieved from http://www.slate.com/articles/life/culturebox/2011/10/generation_catalano_the_generation stuck_between_gen_x_and the_m.html

Shatto, B., \& Erwin, K. (2016). Moving on from Millennials: Preparing for Generation Z. The Journal of Continuing Education in Nursing, 47(6), 253-254. doi:10.3928/0022012420160518-05

Shatto, B., \& Erwin, K. (2017). Teaching Millennials and Generation Z: Bridging the generational divide. Creative Nursing, 23(1), 24-28. doi:10.1891/1078-4535.23.1.24

Skinner, R. (2015). How millennials are fuelling the need for technology innovation in insurance. National Underwriter Life \& Health, 119(3), 31.

Stankorb, S., \& Oelbaum, J. (2014). Reasonable people disagree about the post-Gen X, preMillennial generation. Retrieved from: https://www.good.is/articles/generation-xennials

Sterbenz, C. (2015). Here's who comes after Generation Z-and they'll be the most transformative age group ever. Retrieved from http://www.businessinsider.com/generationalpha-2014-7-2

Swanzen, R., \& Graham, V. L. (2016). Facilitating active citizenship in students through the strengthening of university-community partnerships. In K. González \& R. Frumkin, Handbook of research on effective communication in culturally diverse classrooms (pp. 284-312). Hersey, PA: IGI Global.

TEDx Talks. (2011, June 10). TEDxSF - Scott Hess: Millennials: Who they are \& why we hate them [Video file]. Retrieved from https://www.youtube.com/watch?v=P-enHH-r_FM

TEDx Talks. (2015, November 18). What do we know about the generation after millennials? Jason Dorsey, TEDxHouston [Video file]. Retrieved from https://www.youtube.com/watch?v=4f1609Q0XGE

TEDx Talks. (2016a, February 19). How to destroy the millennial stereotype: Domenico Randazzo, TEDxMorristown [Video file]. Retrieved from https://www.youtube.com/watch?v=vSDP21kV23Q

TEDx Talks. (2016b, November 15). It's about time we stop shaming Millennials: Lindsey Pollak, TEDxStLouisWomen [Video file]. Retrieved from https://www.youtube.com/watch?v=kaCQ-giZOxg 
International Journal of Child, Youth and Family Studies (2018) 9(2): 125-150

Twenge, J. M., \& Park, H. (2017). The decline in adult activities among U.S. adolescents, 19762016. Child Development, OO(0), 1-17. doi:10.1111/cdev.12930

Valdeavilla, C. (2017, November 14). Generation Z. [Video file]. Retrieved from https://www.youtube.com/watch?v=TgUVQMirzfs

Zeigenhorn, T. L. (2017). There's now a name for the micro generation born between 19771983. Did you know? [Blog post]. Retrieved from https://didyouknowfacts.com/theres-nowa-name-for-the-micro-generation-born-between-1977-1983/ 